\title{
In memoriam: Kenneth Preiss
}

\author{
Yoram Reich • Offer Shai
}

Published online: 8 January 2011

(C) Springer-Verlag London Limited 2011

Prof. Kenneth (Kenny) Preiss passed away on 26/10/2010.

Kenny, Professor Emeritus, at Ben-Gurion University, held the Sir Leon Bagrit chair for 25 years, dealing with Technology and Global Competitiveness. He was an authority on international industrial competitiveness. Over a 35-year career, he has led projects in Israel and the US from enterprise strategy and transformation to technical development. He has held leadership roles to improve operational effectiveness in defense and industrial projects. Kenny was a talented engineer, visionary, founder, and educator. These qualities have made significant stamps on his career.

Kenny was born in South Africa in 1937, studied Civil Engineering and then moved to Israel in 1957 and joined the Israeli Army as a volunteer. Subsequently, he went back to South Africa to continue his study and later to the UK to get his Ph.D. in nuclear engineering in 1964 from Imperial College of Science and Technology, London. Moving to the University of Illinois at Urbana Champaign, he studied nuclear bomb explosions but 2 years later, in 1966, he turned down a tenure position there to come back to Israel.

Shortly after arriving to Israel, he co-founded an R\&D unit in the army, serving as an engineer and leader there for 20 years, developing over 250 products, many of which were documented in a book. Meanwhile, Kenny was one of the founders of Ben-Gurion University of the Negev, at Beer Sheba, Israel.

At the mechanical engineering department of Ben-Gurion University, Kenny was a pioneer in the research and practice of using computers in engineering, in particular in CAD/ CAM. He developed with his student one of the first

Y. Reich $(\bowtie) \cdot$ O. Shai

Tel Aviv, Israel

e-mail: yoram@eng.tau.ac.il commercial CAM software ( $\mathrm{M}^{2} \mathrm{C}$ company) that manufactured the product from the drawing. He was a driving force in wiring all Israeli universities into a network to become the 2nd country after the US with such a facility.

Kenny understood the importance that computers will play in providing "intelligent" support to engineers in design and analysis. He was among the first pioneers to advance Artificial Intelligence in engineering in general and in mechanical engineering in particular, with his 1978 report "Engineering Design Viewed as an Activity in Artificial intelligence," Technical Report 167, SRI International, Menlo Park, CA.

Subsequently, Kenny understood that addressing complex engineering challenges requires more than just support for engineers and he moved on to the engineering management area. In 1991, Kenny was selected by the Iacocca Institute of Lehigh University to analyze the US role in the changing structure of worldwide industry. He was one of the facilitators and a co-editor of the resulting report, "21st Century Manufacturing Enterprise Study: An Industry-Led View". The results of this study were published in two highly recognized books.

1. Agile Competitors and Virtual Organizations: Strategies for Enriching the Customer, Co-Author (Steven L. Goldman, Roger N. Nagel, Kenneth Preiss), Van Nostrand, 1995. [This book has been translated into ten languages and was one of the four finalists for the Booz Allen- Financial Times of London award as best North American Management book of 1995. It has been reissued by John Wiley.]

2. Cooperate to Compete: Building Agile Business Relationships, Co-Author (Kenneth Preiss, Steven L. Goldman, Roger N. Nagel), Van Nostrand Reinhold, 1996 [now John Wiley]. 
This study identified in detail the new emerging, systemwide, dynamic and agile, global competitive environment. The study was used by President Clinton for shaping his policy in related areas.

In the last decade, Kenny shifted his effort completely to management; becoming also a faculty member in the Management School at Ben-Gurion University.

Kenny authored or coauthored over 200 original research papers and reports, and a number of books. He was a member of the editorial board of scientific journals including: Artificial Intelligence in Engineering, Engineering with Computers, and Research in Engineering Design, and the founder and Chief Editor of the journal Agility and Global Competition.

Kenny was also an educator. Not only did he teach courses in mechanical engineering and the school of management, but he also played a major role in shaping the science and technological education in Israel. In his many visits abroad and invited talks, he shared his experience with others. Kenny was a member of the Israeli Council for National Planning; a member of the Planning and Budgets Committee (PBC), National Council for Higher Education, Israel; Chairman of the Board, Israel Center for Teaching of Science and Technology. Kenny was also an advisor to ORT charity foundation on technology education.

For his contributions to engineering research and teaching, he was awarded an honorary membership of the American Society of Mechanical Engineers in 1980. For his life contribution to Computer-Aided Design and to science and technology education in Israel, he was awarded a life contribution award from the Israeli Association of Mechanical Engineers in 2010. 